\title{
Mine Water Treatment in Hongai Coal Mines
}

\author{
Phuong Thao Dang ${ }^{1, *}$, and $V u$ Chi Dang ${ }^{1}$ \\ ${ }^{1}$ Hanoi University of Mining and Geology, Hanoi, Vietnam \\ 18 Vien Street, Duc Thang Ward, Bac Tu Liem District, Hanoi, Vietnam
}

\begin{abstract}
Acid mine drainage (AMD) is recognized as one of the most serious environmental problem associated with mining industry. Acid water, also known as acid mine drainage forms when iron sulfide minerals found in the rock of coal seams are exposed to oxidizing conditions in coal mining. Until 2009, mine drainage in Hongai coal mines was not treated, leading to harmful effects on humans, animals and aquatic ecosystem. This report has examined acid mine drainage problem and techniques for acid mine drainage treatment in Hongai coal mines. In addition, selection and criteria for the design of the treatment systems have been presented. Key words - acid mine drainage, coal mining, mine drainage treatment, Hongai coal mine.
\end{abstract}

\section{Introduction}

Coal mining can have negative impacts on the environment in surrounding area and one of these problems is acid mine drainage (AMD). Acid mine drainage (AMD) is the result of sulfide minerals, typically pyrite in coal seams, where the pyrite is exposed to oxidising conditions in coal mining to produce sulphuric acid $\left(\mathrm{H}_{2} \mathrm{SO}_{4}\right)$ and metal precipitates such as Fe oxyhydroxides (Equation 1) [1].

$$
\mathrm{FeS}_{2}+\frac{7}{2} \mathrm{H}_{2} \mathrm{O}+\frac{15}{4} \mathrm{O}_{2} \rightarrow \mathrm{Fe}(\mathrm{OH})_{3}+2 \mathrm{H}_{2} \mathrm{SO}_{4}
$$

Based on monitoring data on mine drainage in Hongai area, it has been shown that the mine drainage is high concentrations of Iron, Manganese and total suspended solids (TSS), low $\mathrm{pH}$ values. So that, mine drainage must be treated in order to protect stream and to help prevent any problem that can cause pollution in the area.

Until 2009, mine drainage in Hongai area was allowed to discharge into rivers then the sea. However, after that, Vietnam National Coal and Mineral Industries Group (VINACOMIN) take responsibility for dealing with environmental problems.

Drainage treatment systems have been installed to better manage the waste water from coal mines in Hongai area.

\section{Study area}

\subsection{Case Study}

Hongai coal mines are located Quang Ninh coal basin that is situated close to the coast. This coal basin contains hard coals deposited in Upper Triassic. Hongai stage has a thickness

\footnotetext{
Corresponding author: dangphuongthao@humg.edu.vn
} 
of 1500-1800 m containing conglomerates, sandstones, shales, coal shales and anthracite seams.

Effluents from Hongai coal mines are released into Dien Vong river and Mip river and ultimately discharge into the Halong bay, which is classified as world natural heritage by the UNESCO. Climate of this area can be defined as a tropical type, with two seasons: hot and moist summer, and dry and cold winter leading to a variable runoff. The average temperature is from $15-25^{\circ} \mathrm{C}$, and annual mean precipitation of $1832 \mathrm{~mm} /$ year.

Hongai underground coal mines have reached the exploiting yield of 6 million tons of coal with more than 10.000 workers.

\section{Materials and methods}

\subsection{Sampling and analytical procedure}

During the dry season (November, 2016), samples of the mine drainage (before treatment) were collected at underground coal mines in Hongai area such as Bac Bang Danh, Cai Da, Dong Binh Minh, Giap Khau and Ha Lam.

The chemical characteristics of the mine drainage discharge from underground coal mines in Hongai area are shown in Table 1.

Table 1. The chemical characteristics of the mine drainage discharge (before treatment) from underground coal mines in Hongai

\begin{tabular}{|c|c|c|c|c|c|c|}
\hline \multirow[b]{2}{*}{ Parameter } & \multicolumn{5}{|c|}{ Mine } & \multirow[b]{2}{*}{$\begin{array}{l}\text { Vietnamese Industrial } \\
\text { Effluent Limits }\end{array}$} \\
\hline & 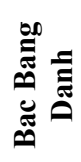 & تََّّ & 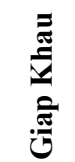 & 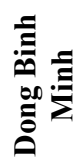 & 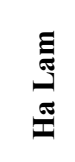 & \\
\hline $\mathrm{pH}$ & 4.2 & 3.4 & 4.63 & 3.71 & 4.62 & $5.5-9$ \\
\hline TSS & 633 & 309 & 539 & 372 & 872 & 100 \\
\hline $\mathrm{Fe}$ & 10.7 & 15.8 & 5.6 & 12.4 & 7.36 & 5 \\
\hline $\mathrm{Mn}$ & 3.4 & 4.2 & 1.9 & 6.1 & 2.01 & 1 \\
\hline
\end{tabular}

The unit for each of the parameters is $\mathrm{mg} / \mathrm{L}$, except for the $\mathrm{pH}$ values

It can be seen from the Table 1 the values of $\mathrm{pH}$ in the mine drainage at various mines in Hongai area are much below than the lower permissible limits of industrial effluent discharge, while TSS, Fe and Mn at there are higher than the permissible industrial limits.

\subsection{Acid Mine Water treatment process in Hongai}

Mine drainage treatment technologies are accomplished by either active or passive treatment systems, both potentially depending on site-specific parameters [2]. Active treatment is the high capital cost and high maintenance costs for continued operation, compared with passive treatment. However, in Hongai area, because of the high volume fluxes and the very limited area for drainage treatment systems, only active treatment is appropriate.

Since 2009, the mine drainage treatment systems have been installed in Hongai area to manage the drainage that comes into the water flow. The system applied is described in Figure 1. This system was proposed by Vietnam National Coal and Mineral Industries Group (VINACOMIN). 


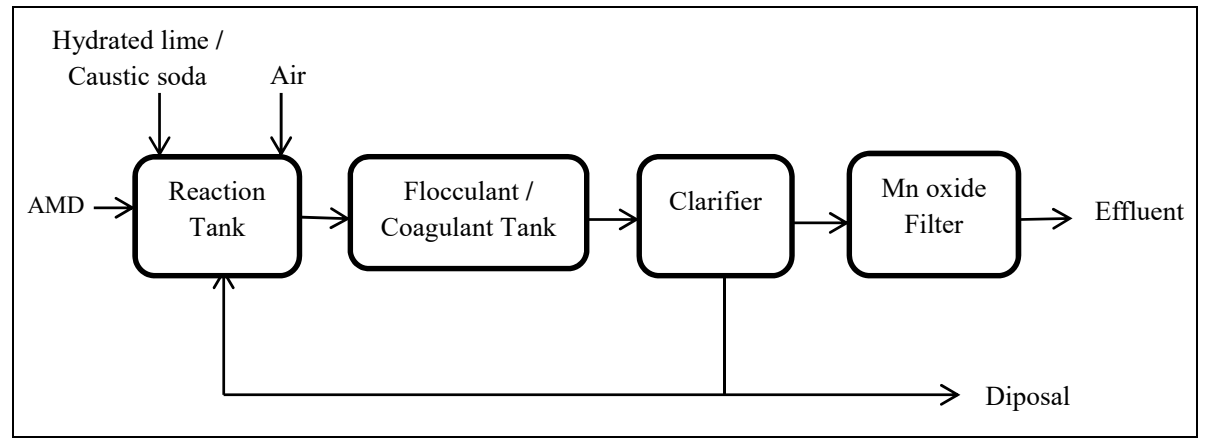

Fig. 1. Scheme of the mine drainage treatment process in Hongai

Mine water treatment is the process that adds chemicals to the water to raise $\mathrm{pH}$ and removes metals.

Typical system of the mine drainage treatment has some steps which are: The drainage is neutralised in a reaction tank with controlled addition of alkali to attain a $\mathrm{pH} 8$ (option). Aeration is added to the reaction tank to oxidize ferrous iron to ferric. The drainage is then contacted to a settling agent and fed to a clarifier for solid/liquid separation. A proportion of sludge collected from the bottom of the clarifier is pumped back into the reaction tank. In order to limit sludge disposal costs, the process decreases sludge volumes by producing higher-density sludge. Manganese is not easily treated by controlling $\mathrm{pH}$ with alkali and separating precipitates; only about $50 \%$ of the Mn load could be removed in a first step at even a $\mathrm{pH}$ of 9.0 by sorption and oxidation in the reactor [3]. Thus the clarified effluent can always be released to manganese oxide filter in order to reduce $\mathrm{Mn}$, and then the effluent can be discharged directly to stream.

This treatment process, which is the standard in the mine drainage treatment, is applied at many underground mines in Hongai area. The process is commonly applied due to its feasibility to treat huge volume of the mine drainage, cost-effect and due to its simplicity.

Based on monitoring data collected at each mine, it was decided to select appropriate treatment process for each mine. To select types of alkali to treat certain mine drainage, it is necessary to consider about acidity levels, flow, the types and concentrations of metals in the mine drainage and cost of alkali [4]. There are two types of alkali in use such as: hydrated lime $\left(\mathrm{Ca}(\mathrm{OH})_{2}\right)$, caustic soda $(\mathrm{NaOH})$ in Hongai coal mines.

To determine the actual alkali requirement, experiments need to be performed. In general, the actual alkali requirement is often higher than calculated alkali, because of other chemicals present. In practice, the correction factor is added to fulfill that requirement.

In Bac Bang Danh mine, Giap Khau mine, Ha Lam mine, hydrated lime is used to neutralise mine drainage. There has to be a machine on site to mechanically add water to the powder that the hydrated lime forms and then delivers it to the mine drainage. Hydrated lime is cheap and easy to handle safely, however, hydrated lime has limited effectiveness if it is required to attain a very high $\mathrm{pH}$.

Amount of lime requirement to reach pH 8 can be calculated as (Equation 2) [5]:

$$
m_{\mathrm{CaO}}=\frac{1.2}{\epsilon} \cdot 500 \cdot\left(10^{-a}+10^{-6}\right) \cdot 56+0.8 \cdot m_{\mathrm{CO}_{2}}+1.8 \cdot m_{\mathrm{Fe}}
$$

where:

$m_{\mathrm{CaO}}$ is the amount of $\mathrm{CaO}, \mathrm{mg} / \mathrm{l}$;

$a$ is the value $\mathrm{pH}$ in the mine drainage before treatment;

$\epsilon$ is the amount of effective $\mathrm{CaO}$ contained in lime involved in the neutralization, $\%$; 
$m_{\mathrm{CO}_{2}}$ is the amount of $\mathrm{CO}_{2}$ in the mine drainage, $\mathrm{mg} / \mathrm{l}$;

$m_{\mathrm{Fe}}$ is the amount of $\mathrm{Fe}$ in the mine drainage, $\mathrm{mg} / \mathrm{l}$;

1.2 value is the correction factor added to adjust the theory value to the actual requirement for lime.

In Cai Da mine, Dong Binh Minh mine, the mine drainage treatment plants, which have low capacity, can be only to treat 50 to $300 \mathrm{~m}^{3} / \mathrm{h}$. The mine drainage is very acidic, $\mathrm{pH}<4$. Caustic soda which is used to neutralise mine drainage can raise the $\mathrm{pH}$ very quickly. However, it is harmful in handling and transporting, also it is more expensive than hydrated lime.

Amount of caustic soda requirement to reach $\mathrm{pH} 8$ can be estimated using the equation below (Equation 3) [5]:

$$
m_{\mathrm{NaOH}}=1.2 \cdot 1000 \cdot\left(10^{-a}+10^{-6}\right) \cdot 40+1.43 \cdot m_{\mathrm{Fe}}
$$

Where:

$m_{\mathrm{NaOH}}$ is the amount of caustic soda, $\mathrm{mg} / \mathrm{l}$;

$a$ is the $\mathrm{pH}$ in the mine drainage before treatment;

$m_{\mathrm{Fe}}$ is the amount of $\mathrm{Fe}$ in the mine drainage, $\mathrm{mg} / \mathrm{l}$;

1.2 value is the correction factor added to adjust the theory value to the actual requirement for caustic soda.

The settling agents, which are coagulant PAC (Poly aluminium chloride) and flocculant PAM (Polyacrylamide), are used to increase particle settling efficiency. Concentrations of PAM and PAC added in the mine drainage are about $0.2-1 \mathrm{mg} / \mathrm{l}$ and $25--45 \mathrm{mg} / \mathrm{l}$, respectively.

The reaction tank built during period of 2009-2010 design provides for a hydraulic residence time between 6 and $10 \mathrm{~min}$. After this period, the reaction tank is required to design large to in order to complete dissolution time of the solids about 10-20 min.

Due to seasonal change the quality and quantity of the mine drainage are not stable [5]. During rainy season, precipitation events in Hongai area have led both to increases and to decreases in $\mathrm{pH}$, and in the concentration of metals [6]. Therefore, amount of alkali requirement for neutralization needs to adjust adequately.

In addition, in Hongai area, the amount of the mine drainage goes to treatment system is higher in the rainy season than to the dry season. The capacities of the mine drainage treatment plants are sometime overload about $117-142 \%$. Therefore, since 2013, in the treatment plant, a stored tank has to be built in order to adjust amount of the mine drainage flow into the reaction tank adequately with extreme events caused by seasonal change.

Acid mine drainage is being treated in coal mines in Hongai area. There are treatment systems today that are installed to manage the drainage that comes into the water flow and these systems are all variably successful.

Based on monitoring data, it has been shown that the treated effluents appear clear and get runoff concentrations of $0.03-0.49 \mathrm{mg} / \mathrm{L} \mathrm{Fe}, 0.07-0.47 \mathrm{mg} / \mathrm{L} \mathrm{Mn}, 13-27 \mathrm{mg} / \mathrm{L}$ total suspended solids (TSS) and $\mathrm{pH}$ range about 7-9 [7]. Mine effluents are treated to meet Industrial Effluent Limits by Vietnamese standard.

Mine water that has been treated can be used in mining operations such as spraying dust, cleaning, etc. in mine.

\section{Conclusion}

Coal mining has a long history in Hongai area, however, mining activities are associated with acid drainage problem that can cause a harmful affect on the natural ecosystem of rivers. 
Therefore, the treatment of the mine drainage in coal mine is required by both VINACOMIN and Viet nam government as a critical requirement of long-term operation.

Nowadays, there are systems that are installed in Hongai area with total designed capacity of $8,560 \mathrm{~m}^{3} / \mathrm{h}$ in order to ensure that the mine drainage from mining area has to be treated appropriately before discharging into the environment.

In general the mine drainage treatment process investigated is suitable for Hongai underground coal mines. Treatment plans generally remove pollutants from mine water quite effectively, however, the operating costs, maintenance costs and the capital need to be considered.

Practical aspect needs to consider such as calculation of the needed alkalinity to raise the $\mathrm{pH}$ high enough, thus reduced operating costs.

In addition, seasonal change leading to a highly variable runoff that is expected to increase the risk of pollution in the drainage treatment. So that, taking seasonal change into account so as to avoid failures of the treatment plant during extreme events.

\section{Acknowledgements}

Authors would like to thank to VINACOMIN Hongai coal company Team for the support with site access and field investigation.

\section{References}

1. A. Azapagic, Developing a Framework for Sustainable Development Indicators for the Mining and Minerals Industry, Journal of Cleaner Production, 12 (6), pp. 639-662, (2004)

2. D. Trumm, Selection of Active and Passive Treatment System for AMD-Flow Chart for New Zealand Conditions. Journal of Geology and Geophysics, 53, pp. 195-210, (2010)

3. F. Bilek, K. Brömme, H. Stolpe, Active Treatment of Fe-, Mn- and Coal dust Contaminated Mine Water as Part of the RAME-Project in Vietnam, [in:] 11 th IMWA Congress ,Mine water - Managing the challenges“, September 4th-11th 2011, Aachen, Germany, pp. 281-286, (2011)

4. International Network for Acid Prevention (INAP). Global Acid. Rock Drainage Guide, http://www.gardguide.com/index.php?title=Chapter_7

5. T. Mien, Mine waste water management and treatment in coal mines in Vietnam. Geosystem Engineering, 15 (1), pp. 66-70, (2012)

6. Công ty $\mathrm{CP}$ Tin học, Công nghệ, Môi trường VINACOMIN. Xây dựng định mức kinh tế, kỹ thuật vận hành các trạm xử lý nước thải mỏ than. Báo cáo tổng kết kết quả nghiên cứu của đề tài, tr. $66,(2016)$

7. P.T. Dang, Master Thesis in Vietnamese, (2017) 